\title{
Diversity Analysis and Genetic Relationships among Local Brazilian Goat Breeds Using SSR Markers
}

\author{
Marcos Paulo Carrera Menezes ${ }^{1}$, Amparo Martinez Martinez ${ }^{2}$ (1), \\ Edgard Cavalcanti Pimenta Filho ${ }^{3}$, Jose Luis Vega-Pla ${ }^{4}{ }^{(0)}$, Juan Vicente Delgado ${ }^{2}{ }^{(0)}$, \\ Janaina Kelli Gomes Arandas ${ }^{5,+}$ (D), Laura Leandro da Rocha ${ }^{5}$ and Maria Norma Ribeiro ${ }^{5, *, \ddagger} \neq$ \\ 1 Departamento de Agropecuária, Universidade Federal da Paraiba, Bananeiras 558220-000, Brazil; \\ marcoscarrera@cchsa.ufpb.br \\ 2 Departamento de Genetica, Universidad de Córdoba, 14071 Cordoba, Spain; \\ amparomartinezuco@gmail.com (A.M.M.); juanviagr218@gmail.com (J.V.D.) \\ 3 Departamento de Zootecnia, Universidade Federal da Paraíba, Areia 58397-000, Brazil; \\ edgardpimenta@hotmail.com \\ 4 Laboratorio de Genética Molecular, Servicio de Cría Caballar y Remonta, 14071 Córdoba, Spain; \\ jvegpla@oc.mde.es \\ 5 Departamento de Zootecnia, Universidade Federal Rural de Pernambuco, Recife 55171-900, Brazil; \\ janaina_arandas@hotmail.com (J.K.G.A.); laura_rocha77@yahoo.com.br (L.L.d.R.) \\ * Correspondence: maria.nribeiro@ufrpe.br \\ + Scholarship at FACEPE (Foundation support of Pernambuco State). \\ $\ddagger$ Scholarship at CNPq (National Council for Scientific and Technological Development).
}

Received: 17 September 2020; Accepted: 6 October 2020; Published: 10 October 2020

Simple Summary: This study aimed to evaluate the genetic diversity of six groups of native Brazilian goats using a panel of single sequence repeats (SSRs). Results indicated a definite genetic differentiation among the Brazilian goat herd, which indicates the existence of at least four breeds according to the international concepts (Moxoto and Repartida; the Grauna and Serrana Azul; Canindé and Marota breeds).

Abstract: The genetic diversity of six Brazilian native goats was reported using molecular markers. Hair samples of 332 animals were collected from different goat breeds (Moxotó, Canindé, Serrana Azul, Marota, Repartida, and Graúna) from five states of Northeast Brazil (Paraíba, Pernambuco, Rio Grande do Norte, Bahia, and Piauí). A panel of 27 microsatellites or single sequence repeats (SSRs) were selected and amplified using a polymerase chain reaction (PCR) technique. All populations showed an average allele number of over six. The mean observed heterozygosity for Brazilian breeds was superior to 0.50 . These results demonstrated the high genetic diversity in the studied populations with values ranging from 0.53 (Serrana Azul) to 0.62 (Repartida). The expected average heterozygosity followed the same trend ranging from 0.58 (Serrana Azul) to 0.65 (Repartida), and the values obtained are very similar for all six breeds. The fixation index (Fis) had values under $10 \%$ except for the Moxotó breed (13\%). The mean expected heterozygosity of all Brazilian populations was over 0.50. Results indicated a within-breed genetic variability in the Brazilian breeds based on the average number of alleles and the average observed heterozygosity. The interbreed genetic diversity values showed proper genetic differentiation among local Brazilian goat breeds.

Keywords: genetic conservation; molecular markers; genetic distance; heterozygosis; animal genetic resources 


\section{Introduction}

Many domestic species originating in Europe were introduced to America in the colonial period. Brazilian goat breeds are derived mainly from Portuguese settlers with animals since the 16th century [1,2]. The Brazilian goat breeds were developed in the national territory due to natural and artificial selection promoted by smallholders, emphasizing the morphology and fitness traits and other associated processes like genetic drift [1]. They developed unique traits such as rusticity, prolificacy, and disease resistance [3], becoming a vital economic resource to household communities.

In addition to early Iberian introductions, Asian breeds (Bhuj, Jamnapari, Mambrina, and Angorá) were introduced. Recently, goats of European breeds (Alpine, Saanen, Toggenburg, and Murciano-Granadina) and African breeds (Anglo-Nubian and Boer) have been imported into Brazil to improve milk and meat productions.

Brazil has more than ten million goat heads, according to FAOSTAT [4]. Approximately $90 \%$ of the national herd consists of animals with no defined breed pattern (NDBP) originating from indiscriminate crossbreeding between foreign and local breeds. However, there are two officially recognized local breeds (Moxotó and Canindé), and other local ecotypes (Serrana Azul, Repartida, Marota, Graúna, and Gurguéia) named according to their origin region or a particular trait. Otherwise, since 2015, these genetic resources are officially recognized as locally adapted breeds, local, or autochthonous breeds (Biodiversity Law. Law No. 13.123/15) [5]. According to a new international breed classification system, local breeds occur only in one country [4].

The local Brazilian goat breeds Moxotó, Canindé, Serrana Azul, Marota, Repartida, and Graúna, are animals of multiple functions and adapted to the climatic conditions and smallholder farming systems. They are rustic animals with less nutritional requirements, raised extensively, and survive in areas where they predominately forage foe food with low nutritional value, unsuitable for foreign breeds. These breeds are the only source of animal protein for low-income populations in the semiarid northeast. Despite the historical and social importance of these breeds, they have been undervalued for decades due to their low contribution to the national economy and their concentration in the most impoverished Brazilian region. This fact has contributed to limited scientific knowledge about these valuable genetic resources.

Another risk factor is that in the last years, the introduction of highly specialized foreign breeds in the Brazilian herds has caused a fast replacement and genetic erosion of the local ones, as observed by [6] and [7]. This situation requires conservation programs to protect the remaining genetic diversity in these local populations. Since the maintenance of these breeds is essential to guarantee an appropriate level of livestock biodiversity and the smallholder family's maintenance.

Accurate knowledge of genetic resource diversity is fundamental for properly targeting conservation strategies and using these resources. Genetic characterization of animals through molecular markers had it shown efficient to quantify genetic variation in different populations.

This study aimed to use molecular markers (microsatellites) to determine the genetic variation between local Brazilian goats.

\section{Materials and Methods}

Random samples were collected from 332 Brazilian goats: 60 Moxotó, 50 Canindé, 55 Serrana Azul, 68 Marota, 52 Repartida, and 47 Grauna (Supplementary Figure S1). DNA was extracted from 10 selected hairs from each animal according to the methodology proposed by Walsh et al. [8] using the same 27 single sequence repeats (SSRs) studied by Menezes et al. [9] (Supplementary Table S1) were amplified and PCR products were separated by electrophoresis in an automatic sequencer ABI 377XL (Applied Biosystems, Foster City, CA, USA).

The PCR products were accomplished both by the internal size standard and by the same reference sample to correct the few variations in allele size assignation among runs. GENETIX v4.04 software [10] was used to calculate allele number, observed, and unbiased expected heterozygosity estimates within breeds [11]. Distribution of gene variation within and between breeds was estimated, 
according to Wright [12] F-statistics using Weir and Cockerham's [13] method. The genetic distance, DA [14], was estimated using the POPULATIONS 1.2.28 [15] computer program. Distances between each pair of populations were used to build a UPGMA tree [16], and a Bootstrap resampling test $(n=1000)$ was performed to verify the dendrogram robustness. Factorial Correspondence Analysis [17] was performed to test the possible admixtures between the populations using the module "AFC sur populations" of the GENETIX v4.04 software.

\section{Results and Discussion}

Genetic variation within breed and fixation index $\left(\mathrm{F}_{\mathrm{is}}\right)$ of Brazilian goat breeds are presented in Table 1. All populations showed an average allele number of over six. The mean observed heterozygosity for Brazilian breeds was higher to 0.50 . These results demonstrated the high genetic diversity in the studied populations with values ranging from 0.53 (Serrana Azul) to 0.62 (Repartida). The expected average heterozygosity followed the same trend ranging from 0.58 (Serrana Azul) to 0.65 (Repartida), and the values obtained are very similar for all six breeds. The fixation index $\left(\mathrm{F}_{\mathrm{is}}\right)$ had values under 10\% except for the Moxotó breed (13\%).

Table 1. The number of samples (n), the average number of alleles (Na), average observed heterozygosity (Ho), the average expected heterozygosity $(\mathrm{He})$, and $\mathrm{F}_{\mathrm{IS}}$ values of the Brazilian breeds.

\begin{tabular}{cccccc}
\hline Populations & $\mathbf{n}$ & $\mathbf{N a}$ & $\mathbf{H o}$ & $\mathbf{H e}$ & $\mathbf{F}_{\mathbf{I S}}(\mathbf{I C}=\mathbf{9 5} \%)$ \\
\hline Serrana Azul & 55 & 6.22 & 0.53 & 0.58 & $0.06(-0.01-0.09)$ \\
Moxotó & 60 & 6.29 & 0.55 & 0.62 & $0.11(0.06-0.15)$ \\
Marota & 68 & 6.07 & 0.58 & 0.61 & $0.04(-0.02-0.07)$ \\
Canindé & 50 & 6.15 & 0.60 & 0.64 & $0.05(-0.01-0.08)$ \\
Repartida & 52 & 6.70 & 0.62 & 0.65 & $0.07(0.02-0.09)$ \\
Graúna & 47 & 6.56 & 0.61 & 0.62 & $0.03(-0.03-0.07)$ \\
\hline Overall & 332 & 6.32 & 0.58 & 0.62 & \\
\hline
\end{tabular}

The mean expected heterozygosity $\left(\mathrm{H}_{\mathrm{e}}\right)$ of all Brazilian populations was over 0.50 . The Serrana Azul was the breed with the lowest value (0.53). The matrix of $D_{A}$ genetic distances [14] among Brazilian breeds and $\mathrm{F}_{\mathrm{ST}}$ among population pairs are showed in Table 2. The smallest genetic distance observed was between Serrana Azul and Graúna breeds, and the highest genetic distance between Serrana Azul and Canindé breeds. This situation was similar to the $\mathrm{F}_{\mathrm{ST}}$ values.

Table 2. Matrix of genetic distance DA between pairs of Brazilian breeds (below diagonal) and $\mathrm{F}_{\mathrm{ST}}$ between pairs of populations (above diagonal).

\begin{tabular}{ccccccc}
\hline Populations & Serrana Azul & Moxotó & Marota & Canindé & Repartida & Graúna \\
\hline Serrana Azul & & 0.084 & 0.087 & 0.105 & 0.104 & 0.036 \\
Moxotó & 0.124 & & 0.072 & 0.045 & 0.051 & 0.073 \\
Marota & 0.143 & 0.110 & & 0.097 & 0.082 & 0.066 \\
Canindé & 0.145 & 0.100 & 0.144 & & 0.047 & 0.089 \\
Repartida & 0.140 & 0.086 & 0.121 & 0.097 & & 0.085 \\
Graúna & 0.082 & 0.130 & 0.130 & 0.144 & 0.139 & \\
\hline
\end{tabular}

The average DA among all populations was 0.122 , which indicates a clear split of the different Brazilian breeds as confirmed by the average FST value (0.075). The differences can be observed in the dendrogram built through the UPGMA method (Figure 1). Two different groups were identified: the first formed by Repartida, Moxotó, Canindé, and Marota. Serrana Azul and Graúna formed the second group. The Bootstrap values ranged from 0.59 to 0.95 , showing the degree of confidence in the topology. 


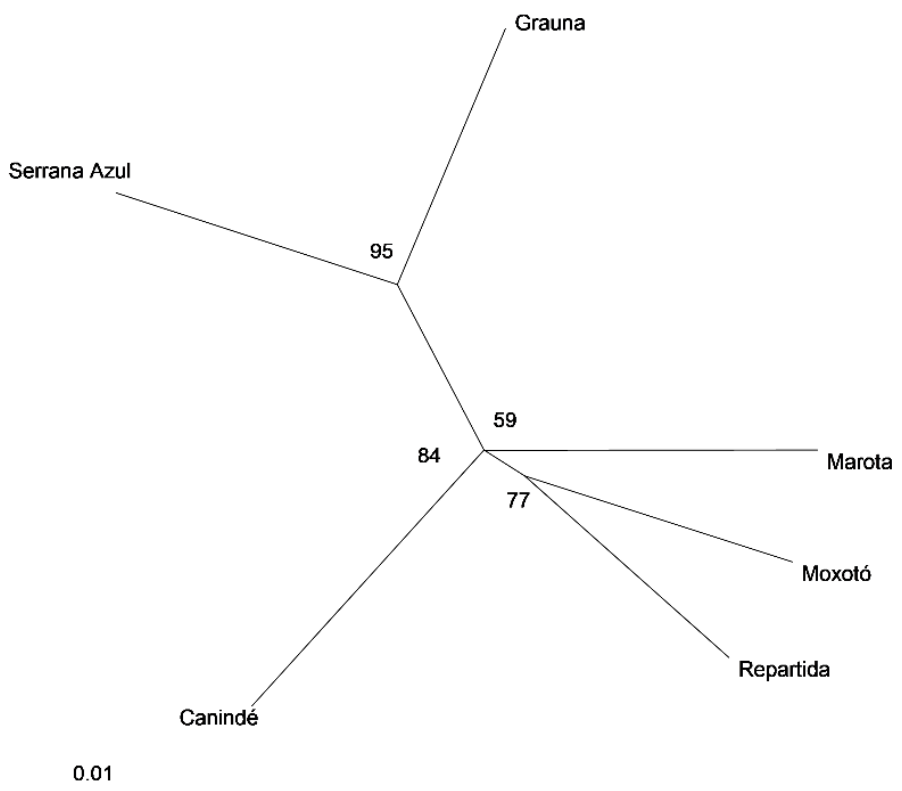

Figure 1. UPGMA dendrogram of Brazilian breeds, based on $\mathrm{D}_{\mathrm{A}}$ distance [14].

The numbers on the nodes are percentage bootstrap values from 1000 replications of resampled loci. The factorial analysis (Figure 2) showed more than $54 \%$ of the total variation in the two first axes, indicating high confidence and genetic relationship among populations. A study conducted using 13 microsatellites with six indigenous Iranian goat populations observed two main groups based on the phylogenetic tree and FCA analysis [18].

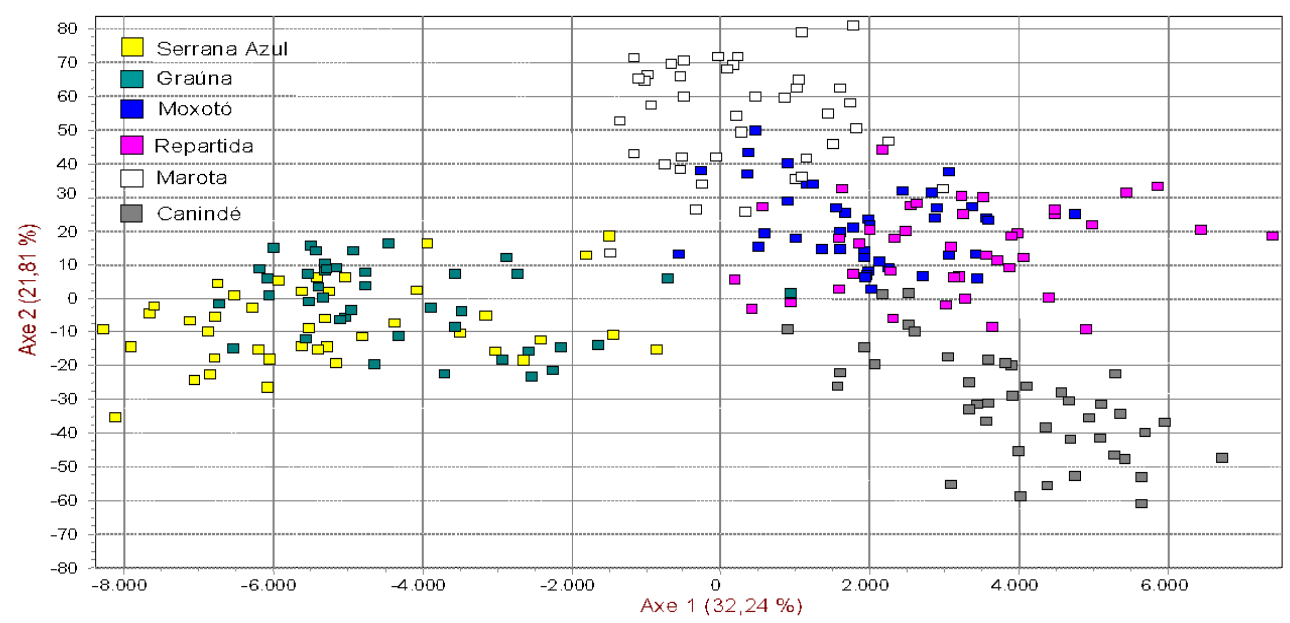

Figure 2. Spatial representation of Brazilian breeds using factorial correspondence analysis.

Ibnelbachyr et al. [19], evaluating the genetic differentiation of Moroccan goat breeds using 12 microsatellite DNA markers, found $64 \%$ of the total variation in the first three factors, whereas Bulut et al. [20] evaluating the genetic diversity of eight domestic goat populations raised in Turkey with 11 microsatellites loci, obtained $47 \%$ of the total variation of the first three factors.

The average number of alleles was higher than those found in different studies with goats in several regions globally, including some breeds in the Americas [21] and the Chinese breed of Daiyun goat [22]. However, the highest number of alleles was reported above 7 in other goat populations in Turkey [20], Marrocos [19], and Saudi Arabia [23]. The higher number of alleles presented by these studies, according to the authors, is justified by the gene flow, the location of the countries on migration routes, and the proximity of the initial centers of domestication, being the vast allelic diversity found 
very useful for selection. Differences in the mean number of alleles can also be influenced by the sample size and the number and type of microsatellites used.

Recent studies evaluating the genetic diversity of Brazilian goat breeds using microsatellite markers observed high levels of observed and expected heterozygosity and suggested substantial genetic diversity in the evaluated breeds.

The average heterozygosity observed in our study was higher than that reported by Silvestre et al. [24] (0.385) in Nubian goats in Brazil. On the other hand, Hossam Mahmoud et al. [23] obtained mean heterozygosity higher than 0.91 , in the local Saudi Arabia goat breed.

According to Jianmin and Wenbin [25], in improved breeds, introgression and gene exchange are widespread, mainly increasing heterogeneity in the population.

Only in the Moxotó breed, the $\mathrm{F}_{\mathrm{IS}}$ value was higher than 0.10 . The $\mathrm{F}_{\mathrm{IS}}$ values in the studied populations shown genetic homogeneity. The high $\mathrm{F}_{\mathrm{IS}}$ value in the Moxotó breed (0.13) may be due to structure with subdivision into herds and low gene flow among the herds. Our samples were collected from four different herds that were geographically and reproductively isolated, and each of these populations is generally closed with a reduced number of sires, which favors inbreeding. In conservation programs, inbreeding levels should be taken into account, mainly when the same male is used for a prolonged period.

The low $\mathrm{F}_{\text {IS }}$ values obtained in our study were contrasting with those found by other authors in goat populations [24,26-28].

The degree of genetic differentiation $\left(\mathrm{F}_{\mathrm{ST}}=0.075\right)$ among all populations was predictable, recent studies have already indicated this degree of differentiation of our Brazilian goats [1], and Frankham et al. [29] suggest that $\mathrm{F}_{\mathrm{ST}}$ values between 0.05 and 0.3 are typical of differentiated livestock breeds. In the European goat breeds, the $\mathrm{F}_{\mathrm{ST}}$ lies around $5 \%$.

The genetic makeup of the Brazilian goat breeds has been influenced by breeds of the Iberian Peninsula and even West African [21,30-32], promoting gene flow between the Iberian Peninsula, northern Africa, and the Canary Islands and Cape Verde [33-35]. Currently, Brazilian goat breeds are genetically distinct with a clear differentiation even from their possible ancestors [1,6,36-38]

As pointed out before, the Brazilian goat herds are very concentrated in one specific region, so that gene flow among breeds must be shared, especially considering that the herd book is either not ongoing or is very rudimentary. Despite this, close breeding management produces some "family" effect within breeds. In general, the average number of alleles and the mean heterozygosity obtained in this work suggest a high genetic diversity within the Brazilian goat breeds. These breeds are also targeted to crossbreeding with exotic and with each other Brazilian local goat breed, as reported by Rocha et al. [6].

The use of crosses within the local breeds is widespread in Brazil, as observed in our research (Figure 1). Those with the exotic breeds were sufficient to consider establishing a genetic conservation program for Brazilian indigenous goat populations.

Therefore, efficient herd management is vital to the conservation of these genetic resources by avoiding breeding with related individuals, exchanging individuals among herds, and increasing the effective number.

The UPGMA dendrogram (Figure 1) constructed with the $\mathrm{D}_{\mathrm{A}}$ genetic distance values grouped Serrana Azul and Graúna and performed another group joining Moxotó, Repartida, and Marota. The proximity of Moxotó and Repartida could be explained by the genetic composition of the Repartida ecotype, which arose by segregation within Moxotó, differing only in coat color.

Despite the geographical distance among the Moxotó and Canindé, these breeds probably shared the same gene pool.

The correspondence factorial analysis showed the same distribution of the populations, but in this case, the Marota and Canindé breeds were distant from the others. It was not possible to separate Moxotó and Repartida breed, and this fact was well explained before.

The Marota have had a higher genetic distance with each other breeds and, it could be due to a genetic drift effect promoted by founder effect and geographic isolation. There is a high similarity 
between the Serrana Azul and Grauna breeds. There was gene flow between the two groups favoring a smaller genetic distance among them. The breeders have only recently separated these populations based on the coat color pattern, and there has not been a genetic differentiation other than the few loci involved in the coat color determination.

\section{Conclusions}

A significant genetic differentiation among the Brazilian goat breeds was verified, which indicates the existence of at least four breeds according to the international concepts (Moxotó and Repartida; the Grauna and Serrana Azul; Canindé and Marota breed).

The genetic diversity and differentiation among the local Brazilian goat breeds must be safeguarded through in-situ and ex-situ conservation actions, integrated into local development programs.

Supplementary Materials: The following are available online at http://www.mdpi.com/2076-2615/10/10/1842/s1, Figure S1: Brazilian goat breeds, Table S1: Microsatellites analyzed, fragment sizes, fluorochromes, and the respective sequences (direct and reverse) of the primers.

Author Contributions: Responsible for the development of research and preparation of the scientific article derived from the doctoral thesis of the first author, M.P.C.M.; contribution to the scientific review of the article. A.M.M., E.C.P.F., J.L.V.-P., J.V.D., and J.K.G.A.; contribution to the development of research and scientific review of the content of the article, L.L.d.R.; project coordinator, contribution to the development of research and scientific review of the content of the article, M.N.R. All authors have read and agreed to the published version of the manuscript.

Funding: This research was funded by CAPES, CNPq and the Andalucian Research Group “Mejora y Conservación de los Recursos Genéticos de los Animales Domésticos" (AGR218) sited at the University of Córdoba (Spain) as part of their efforts to improve the genetic diversity of the domestic animals.

Conflicts of Interest: The authors declare no conflict of interest.

\section{References}

1. Ribeiro, M.N.; Bruno-de-Sousa, C.; Martinez-Martinez, A.; Ginja, C.; Menezes, M.P.C.; Pimenta-Filho, E.C.; Delgado, J.V.; Gama, L.T. Drift across the Atlantic: Genetic differentiation and population structure in Brazilian and Portuguese native goat breeds. J. Anim. Breed. Genet. 2012, 129, 79-87. [CrossRef] [PubMed]

2. Primo, A.T. El ganado bovino Iberico en las Americas: 500 anos despues. Arch. Zootec. 1992, 41, 421-432.

3. Mariante, A.S.; Albuquerque, M.S.M.; Egito, A.A.; McManus, C. Advances in the Brazilian animal genetic resources. Anim. Genet. Resour. Inf. 1999, 25, 107-121. [CrossRef]

4. FAOSTAT. Live Animals. 2018. Available online: inhttp://www.fao.org/faostat/en/\#data/QA (accessed on 3 May 2020).

5. Brasil. 2015. Lei $\mathrm{N}^{\mathrm{o}}$ 13.123, DE 20 de Maio de 2015. BRASILIA, DF, Maio de 2017. Available online: http://www.planalto.gov.br/ccivil_03/_Ato2015-2018/2015/Lei/L13123.htm (accessed on 10 September 2020).

6. Da Rocha, L.L.; Filho, E.C.P.; Filho, M.A.G.; Delgado, J.V.; Martínez, A.M.; Ribeiro, M.N. Impact of foreign goat breeds on the genetic structure of Brazilian indigenous goats and consequences to intra-breed genetic diversity. Small Rumin. Res. 2016, 134. [CrossRef]

7. Ribeiro, M.N.; Da Rocha, L.L.; De Carvalho, F.F.R.; Costa, R.G.; Gomes Arandas, J.K.; Ribeiro, N.L. Threatened Goat Breeds from the Tropics: The Impact of Crossbreeding with Foreign Goats. In Sustainable Goat Production in Adverse Environments: Volume I; Springer: Cham, Switzerland, 2018; ISBN 9783319718552.

8. Walsh, P.S.; Metzger, D.A.; Higuchi, R. Chelex 100 as a medium for simple extraction of DNA for PCR-based typing from forensic material. Biotechniques 1991, 10, 506-513. [CrossRef]

9. Menezes, M.P.C.; Martinez, A.M.; Ribeiro, M.N.; Filho, E.C.P.; Bermejo, J.V.D. Caracterização genética de raças caprinas brasileiras utilizando-se 27 marcadores microssatélites. Rev. Bras. Zootec. 2006, 35, 1336-1341. [CrossRef]

10. Belkhir, K.; Borsa, P.; Chikhi, L.; Raufaste, N.; Bonhomme, F. Genetix, Logiciel Sous Windowstm Pour La Génétique des Populations; Laboratoire Génome, Populations, Interactions CNRS UMR 5000, Université De Montpellier II: Montpellier, France, 2000.

11. Nei, M. Analysis of gene diversity in subdivided populations. Proc. Natl. Acad. Sci. USA 1973, 70, 3321-3323. [CrossRef] 
12. Wright, S. The genetic structure of populations. Ann. Eugen. 1951, 15, 323-354. [CrossRef]

13. Weir, B.S.; Cockerham, C. Estimating F-statistics for analysis of population structure. Evolution 1984, $36,1358-1370$.

14. Nei, M.; Tajima, F.; Tateno, Y. Accuracy of estimated phylogenetic trees from molecular data. II. Gene frequency data. J. Mol. Evol. 1983, 19, 153-170. [CrossRef]

15. Langela, O. Populations 1.2.28 CNRS UPR9034. 1999. Available online: http://www.cnrs-gif.fr/pge/bioinfo/ populations/index.php (accessed on 3 May 2020).

16. Sneath, I.H.A.; Sokal, R.R. Numerical Taxonomy; W.H. Freeman and Company: San Francisco, CA, USA, 1973.

17. Lebart, L.; Morineau, A.; Warwick, K. Multivariant Descriptive Statistical Analysis; John Wiley and Sons: New York, NY, USA, 1984.

18. Mahmoudi, B.; Panahi, B.; Mohammadi, S.A.; Daliri, M.; Babayev, M.S. Microsatellite based phylogeny and bottleneck studies of Iranian indigenous goat populations. Anim. Biotechnol. 2014, 25, $210-222$. [CrossRef] [PubMed]

19. Ibnelbachyr, M.; Colli, L.; Boujenane, I.; Chikhi, A.; Nabich, A.; Piro, M. Genetic differentiation of draa indigenous breed and relationships with other goat populations assessed by microsatellite DNA markers. Iran. J. Appl. Anim. Sci. 2017, 7, 621-629.

20. Bulut, Z.; Kurar, E.; Ozsensoy, Y.; Altunok, V.; Nizamlioglu, M. Genetic diversity of eight domestic goat populations raised in Turkey. BioMed Res. Int. 2016, 2016, 2830394. [CrossRef] [PubMed]

21. Ginja, C.; Gama, L.T.; Martínez, A.; Sevane, N.; Martin-Burriel, I.; Lanari, M.R.; Revidatti, M.A.; Aranguren-Méndez, J.A.; Bedotti, D.O.; Ribeiro, M.N.; et al. Genetic diversity and patterns of population structure in Creole goats from the Americas. Anim. Genet. 2017, 48, 315-329. [CrossRef] [PubMed]

22. Liu, G.; Zhao, Q.; Lu, J.; Sun, F.; Han, X.; Zhao, J.; Feng, H.; Wang, K.; Liu, C. Insights into the genetic diversity of indigenous goats and their conservation priorities. Asian Australas. J. Anim. Sci. 2019. [CrossRef] [PubMed]

23. Hossam Mahmoud, A.; Abul Farah, M.; Rady, A.; Mashai Alanazi, K.; Mohammed, O.; Amor, N.; Mohammed Alarjani, K. Molecular characterization of goats from Saudi Arabia using microsatellite markers. J. King Saud Univ. Sci. 2020, 32, 1681-1686. [CrossRef]

24. De Aguiar Silvestre, E.; da Silva Costa, M.; da Silva, P.O.; Bajay, M.M.; Pinheiro, J.B.; Zucchi, M.I.; Campelo, J.E.G.; Britto, F.B. A note on the distribution of genetic diversity of Anglo-Nubian goats in central-northern farms of Piauí, Brazil. Rev. Bras. Zootec. 2015, 44, 155-160. [CrossRef]

25. Jianmin, W.; Wenbin, Y. Genetic relationships of domestic sheep and goats in the lower reaches of the Yellow River based on microsatellite analysis. Biodivers. Sci. 2008, 16, 53. [CrossRef]

26. Hassen, H.; Rischkowsky, B.; Termanini, A.; Jessry, G.; Haile, A.; Baum, M.; Lababidi, S. Morphological and molecular genetic diversity of Syrian indigenous goat populations. Afr. J. Biotechnol. 2016, 15, 745-758. [CrossRef]

27. Hilal, B.; Boujenane, I.; El Otmani, S.; Chentouf, M.; Piro, M. Genetic characterization of Hamra goat population in two different locations of morocco using microsatellite markers. Iran. J. Appl. Anim. Sci. 2016, 6, 901-907.

28. El-Sayed, M.A.; El-Hamamsy, S.M.; Abdelhamed, W.; El-Danasoury, M.M. Genetic diversity in Egyptian goats based on microsatellite markers. Curr. Appl. Sci. Technol. 2017, 17, 130-139.

29. Frankham, R.; Ballou, J.D.; Briscoe, D.A.; McInnes, K.H. Introduction to Conservation Genetics; Cambridge University Press: Cambridge, UK, 2002.

30. Colli, L.; Milanesi, M.; Talenti, A.; Bertolini, F.; Chen, M.; Crisà, A.; Daly, K.G.; Del Corvo, M.; Guldbrandtsen, B.; Lenstra, J.A.; et al. Genome-wide SNP profiling of worldwide goat populations reveals strong partitioning of diversity and highlights post-domestication migration routes. Genet. Sel. Evol. 2018, 50, 58. [CrossRef]

31. Silva, N.M.V.; Pimenta-Filho, E.C.; Arandas, J.K.G.; Medeiros, R.B.N.; Cavalcante-Neto, A.; Fonseca, C.; Ribeiro, M.N. Genetic relationships between local Brazilian goat breeds based on mtDNA D-loop region similarity. Span. J. Agric. Res. 2019, 17, e0407. [CrossRef]

32. Amills, M.; Ramírez, O.; Tomàs, A.; Badaoui, B.; Marmi, J.; Acosta, J.; Sànchez, A.; Capote, J. Mitochondrial DNA diversity and origins of South and central American goats. Anim. Genet. 2009, 40, 315-322. [CrossRef] 
33. Paim, T.D.P.; Faria, D.A.; Hay, E.H.; McManus, C.; Lanari, M.R.; Esquivel, L.C.; Cascante, M.I.; Alfaro, E.J.; Mendez, A.; Faco, O.; et al. New world goat populations are a genetically diverse reservoir for future use. Sci. Rep. 2019, 9, 1476. [CrossRef] [PubMed]

34. Manunza, A.; Noce, A.; Serradilla, J.M.; Goyache, F.; Martínez, A.; Capote, J.; Delgado, J.V.; Jordana, J.; Muñoz, E.; Molina, A.; et al. A genome-wide perspective about the diversity and demographic history of seven Spanish goat breeds. Genet. Sel. Evol. 2016, 48, 52. [CrossRef] [PubMed]

35. Pereira, F.; Queirós, S.; Gusmão, L.; Nijman, I.J.; Cuppen, E.; Lenstra, J.A.; Consortium, E.; Davis, S.J.M.; Nejmeddine, F.; Amorim, A. Tracing the history of goat pastoralism: New clues from mitochondrial and y chromosome DNA in North Africa. Mol. Biol. Evol. 2009, 26, 2765-2773. [CrossRef] [PubMed]

36. Oliveira, J.C.V.; Ribeiro, M.N.; Rocha, L.L.; Gomes-Filho, M.A.; Delgado, J.V.; Martinez, A.M.; Menezes, M.P.C.; Bettencourt, C.M.; Gama, L.T. Genetic relationships between two homologous goat breeds from Portugal and Brazil assessed by microsatellite markers. Small Rumin. Res. 2010, 93, 79-87. [CrossRef]

37. Sevane, N.; Cortés, O.; Gama, L.T.; Martínez, A.; Zaragoza, P.; Amills, M.; Bedotti, D.O.; Bruno De Sousa, C.; Cañon, J.; Dunner, S.; et al. Dissection of ancestral genetic contributions to Creole goat populations. Animal 2018, 12, 2017-2026. [CrossRef] [PubMed]

38. De Oliveira, J.D.; de Paiva Igarashi, M.L.S.; Machado, T.M.M.; Miretti, M.M.; Ferro, J.A.; Contel, E.P.B. Structure and genetic relationships between Brazilian naturalized and exotic purebred goat domestic goat (Capra hircus) breeds based on microsatellites. Genet. Mol. Biol. 2007, 30, 356-363. [CrossRef]

(C) 2020 by the authors. Licensee MDPI, Basel, Switzerland. This article is an open access article distributed under the terms and conditions of the Creative Commons Attribution (CC BY) license (http://creativecommons.org/licenses/by/4.0/). 